\title{
SYNTHESIS AND STRUCTURE OF UREA-FORMALDEHYDE OLIGOMERS WITH PEROXIDE GROUPS
}

\author{
Olena Astakhova', Olena Shyshchak ${ }^{1}$, Michael Bratychak ${ }^{1,}$
}

https://doi.org/10.23939/chcht15.03.369

\begin{abstract}
The possibility of synthesis in the presence of tert-butyl peroxymethanol (TBPM) or tert-butyl hydroperoxide (TBHP) of urea-formaldehyde oligomers with peroxide groups (UFOP) has been considered. Zinc oxide was used as the reaction catalyst. The effect of the initial components ratio, the reaction temperature and the process time on the characteristics and yield of the obtained oligomers was studied. Methods for obtaining UFOP using a mixture of TBPM and TBHP as a component are proposed. The structure of the synthesized UFOP was confirmed by IR- and NMR-spectroscopic studies.
\end{abstract}

Keywords: urea, formaldehyde, urea-formaldehyde oligomers, peroxide, hydroperoxide, zinc oxide, IR- and NMR studies.

\section{Introduction}

The expansion of the scope of polymeric materials in various industries, as well as the increased requirements for the operational properties of the products based on them, dictate the need to create new macromolecular compounds and improve the properties of existing ones [1-4].

The structure of most polymer systems and their compositions is formed in the presence of compounds capable to serve as a source of free radicals under certain temperature conditions [5]. There are, first of all, oligomeric compounds, which contain peroxide or hydroperoxide groups in their structure. Moreover, the presence of other functional groups in the molecules of such compounds, in addition to the $-\mathrm{O}-\mathrm{O}-$ bond, makes it possible to control the processes of polymer production in order to create materials with given properties $[5,6]$. Oligomers with peroxide groups, in comparison with lowmolecular peroxides, are more stable during storage, less toxic and allow to form products by the so-called

Lviv Polytechnic National University

12 Bandery St., Lviv 79013, Ukraine

\mbratychak@gmail.com

(c) Astakhova O., Shyshchak O., Bratychak M., 2021 "casting" technology. Epoxy [5, 7, 8], phenolformaldehyde $[9,10]$ and polyglycedylphenolformaldehyde oligomers [11] are most often used for the synthesis of mentioned oligomers. Epoxy resins are of special attention as starting compounds for the synthesis of peroxide oligomers. Epoxy resins are characterized by unique properties $[12,13]$ and contain reactive epoxy groups in their structure allowing to use resins as starting compounds for the synthesis of peroxide oligomers via the reaction of epoxy group with hydroperoxides and functional peroxides [6].

Apart from the above-mentioned functional resins, aminoformaldehyde compounds deserve special attention [14-17]. Such compounds are used for the creation of various polymer products. The raw materials for obtaining such oligomers are urea and formaldehyde. Therefore, such compounds, in comparison with the abovementioned ones, are quite cheap and available. At the same time, urea-formaldehyde resins are characterized by insufficient solubility in organic solvents and compatibility with other polymers, oligoesteracrylates in particular. This complicates the possibility of their widespread use for the creation of composites. On the other hand, the ureaformaldehyde oligomers contain free reactive methyl groups. This makes it possible to modify them with various low-molecular compounds and thus to extend the areas of their application.

The paper considers the possibility of modifying urea-formaldehyde oligomers with functional peroxide (tert-butyl peroxymethanol and tert-butyl hydroperoxide) in order to introduce peroxide groups into the structure of urea-formaldehyde oligomers. Incomplete substitution of methylol groups for peroxide ones will allow to obtain products with both free methylol groups and peroxide groups. It means that such oligomers can be used in the process of products formation via both the polycondensation method using methylol groups and the polymerization mechanism using peroxide groups. The synthesized oligomers should show greater solubility in organic solvents and compatibility with other polymers. 


\section{Experimental}

\subsection{Materials}

For the synthesis of urea-formaldehyde oligomers with peroxide groups (UFOP) we used urea of PA grade without additional purification $(\mathrm{mp} 405.1 \mathrm{~K}$; lit. data $405.7 \mathrm{~K}[18]$ ) and formaldehyde in the form of $38-40 \%$ aqueous solution [18].

tert-Butyl hydroperoxide (TBHP) was obtained by the method described in [19]. After vacuum distillation at $308-310 \mathrm{~K}$ and residual pressure of $13-14 \mathrm{kPa}$ a product with the following characteristics was obtained:

$$
n_{D}^{20}=1.4006, d_{4}^{20}=0.8961
$$

(lit. data bp $310 \mathrm{~K} / 13 \mathrm{kPa}$,

$$
\left.n_{D}^{20}=1.4006, d_{4}^{20}=0.8960\right) \text {. }
$$

tert-Butyl peroxymethanol (TBPM) was obtained in a three-necked reactor equipped with a mechanical stirrer, reflux condenser and thermometer. $79.0 \mathrm{~g}$ of formalin (38\% solution), $90.1 \mathrm{~g}$ of TBHP and $0.51 \mathrm{~g}$ of zinc oxide were loaded into the reactor. The mixture was kept under stirring at room temperature for $1 \mathrm{~h}$. The organic layer was separated, washed with water and dried over magnesium sulfate. The resulting product was separated by vacuum distillation at $320 \mathrm{~K}$ and residual pressure of $10 \mathrm{kPa}$. The resulting TBPM $(102.2 \mathrm{~g}, 85.2 \%)$ had the following characteristics: $n_{D}^{20}=1.4128, d_{4}^{20}=$ 0.9684, MR 30.92 (calculated MR 30.79).

Zinc oxide of PA grade was used without additional purification.

\subsection{Methods of Analyses}

Content of active oxygen ([O $\left.]_{a c t}, \%\right)$ was determined by the iodometric method [20], the content of methylol groups - by the method described in [21]; molecular weight of oligomers -by isopiestic method [22].

IR-spectra were measured by means of the Nicolet 8700 spectrometer (Thermo Scientific, Waltham, MA) equipped with the GoldenGate ATR accessory (Specac Ltd., Orpington, Great Britain). A single-reflection diamond crystal was used as the internal reflection element of the accessory. For each spectrum 256 scans were taken with the resolution of $4 \mathrm{~cm}^{-1}$. The temperature was set at $298 \mathrm{~K}$ with using an electronic temperature controller (Specac Ltd., Orpington, Great Britain). All spectra were collected and analyzed using the commercially available software: OMNIC (Thermo Scientific, Waltham, MA), Matlab (MathWorks, Natic, MA).

NMR spectra were recorded at $400 \mathrm{MHz}$, using Bruker Avance II 400 spectrometer (Poland) in deuterochloro-form at room temperature.

\subsection{Kinetic Studies}

The process of UFOP obtaining was studied in a three-necked reactor, which was loaded with urea, formalin, peroxide or hydroperoxide and zinc oxide. The reaction was controlled according to the consumption of one of the components of the reaction mixture. The oligomer yield was calculated in $\mathrm{g}$ per $100 \mathrm{~g}$ of starting urea.

\subsection{Methods of UFOP Synthesis}

Peroxide oligomer based on urea-formaldehyde resin and TBPM (UFOP-I) was synthesized in a threenecked reactor with a mechanical stirrer, thermometer and reflux condenser. The reactor was loaded with $30 \mathrm{~g}$ of urea $(0.5 \mathrm{~mol}), 150 \mathrm{~g}$ of $40 \%$ aqueous formalin solution containing $60 \mathrm{~g}(2 \mathrm{~mol})$ of formaldehyde, $180 \mathrm{~g}(1.5 \mathrm{~mol})$ of TBPM and $0.21 \mathrm{~g}\left(25.8 \cdot 10^{-4} \mathrm{~mol}\right)$ of zinc oxide. The reaction mixture was kept at $343 \mathrm{~K}$ for $3 \mathrm{~h}$, then filtered and vacuumized at $328-333 \mathrm{~K}$ and residual pressure of 1$3 \mathrm{kPa}$ for $2 \mathrm{~h} .113 \mathrm{~g}$ of UFOP-I were obtained.

Peroxide oligomer based on urea-formaldehyde resin and TBHP (UFOP-II) was synthesized similarly to UFOP-I, based on $30 \mathrm{~g}(0.5 \mathrm{~mol})$ of urea, $316 \mathrm{~g}$ of $38 \%$

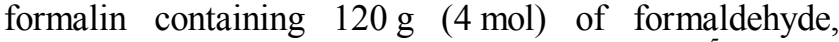
$225.4 \mathrm{~g}(2.5 \mathrm{~mol})$ of TBHP and $0.3 \mathrm{~g}\left(36.8 \cdot 10^{-5} \mathrm{~mol}\right)$ of zinc oxide. $117 \mathrm{~g}$ of UFOP-II were obtained.

\section{Results and Discussion}

\subsection{Synthesis of Urea-Formaldehyde Oligomers}

The synthesis of urea-formaldehyde oligomers with peroxide groups (UFOP) can be represented by the following equation:

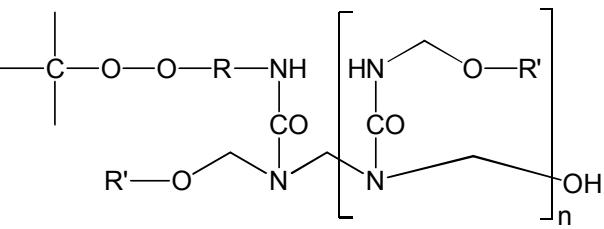

where $\mathrm{X}=-\mathrm{H}, \mathrm{HOCH}_{2-} ; \mathrm{R}=-\mathrm{CH}_{2}-,-\mathrm{CH}_{2}-\mathrm{O}-\mathrm{CH}_{2}-; \mathrm{R}^{\prime}=-\mathrm{H},-\mathrm{OC}\left(\mathrm{CH}_{3}\right)_{3},-\mathrm{CH}_{2} \mathrm{OOC}\left(\mathrm{CH}_{3}\right)_{3} ; \mathrm{n}=0-2$. 
tert-Butyl peroxymethanol (TBPM) and tert-butyl hydroperoxide (TBHP) were used as compounds responsible for the presence of peroxide groups in the synthesized oligomers. The reaction catalyst was zinc oxide.

\subsubsection{Synthesis of UFOP in the presence of TBPM}

To determine the optimal conditions for the synthesis of UFOP in the presence of TBPM, the effect of the starting reagents ratio, temperature and process time on the content of active oxygen and methylol groups in the synthesized oligomer was studied. Moreover, the effect of synthesis conditions on the yield of peroxide oligomer, its solubility in organic solvents and the ability to combine with unsaturated oligoesters was examined. The reaction was studied for urea $(\mathrm{U})$ : formaldehyde (F) : TBPM molar ratio equal to $1:(2-10):(1-9)$. The reaction was carried out at $323,333,343$ and $353 \mathrm{~K}$ for $0.5-6 \mathrm{~h}$; the amount of zinc oxide was $0.7 \mathrm{wt} \%$ relative to the urea content.

The experimental results are shown in Figs. 1-3 and Table 1.

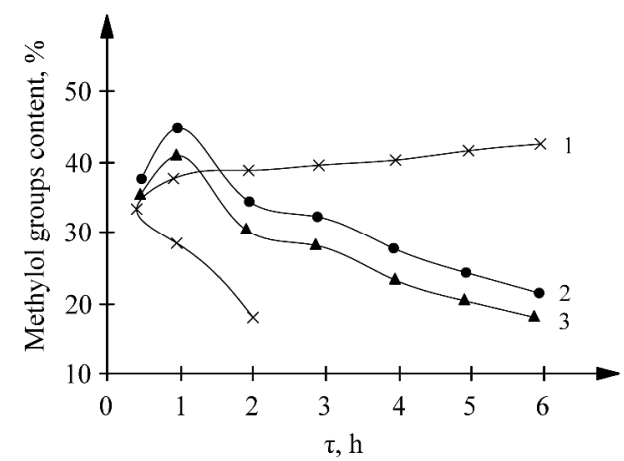

b)

Fig. 1. Content of active oxygen (a) and methylol groups (b) in UFOP depending on reaction time at different temperatures: $323 \mathrm{~K}$ (1); $333 \mathrm{~K}(2) ; 343 \mathrm{~K}(3)$ and $353 \mathrm{~K}(4)$. Molar ratio $\mathrm{U}: \mathrm{F}: \mathrm{TBPM}=1: 4: 3$

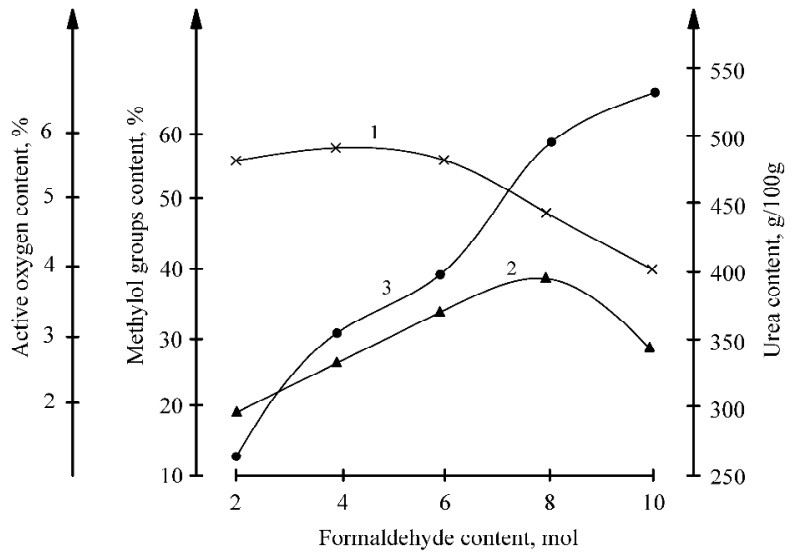

Fig. 2. Content of active oxygen (1) and methylol groups (2) in UFOP and oligomer yield (3) depending on the F content. Molar ratio $\mathrm{U}: \mathrm{TBPM}=1: 3 ; T=343 \mathrm{~K} ; t=3 \mathrm{~h}$
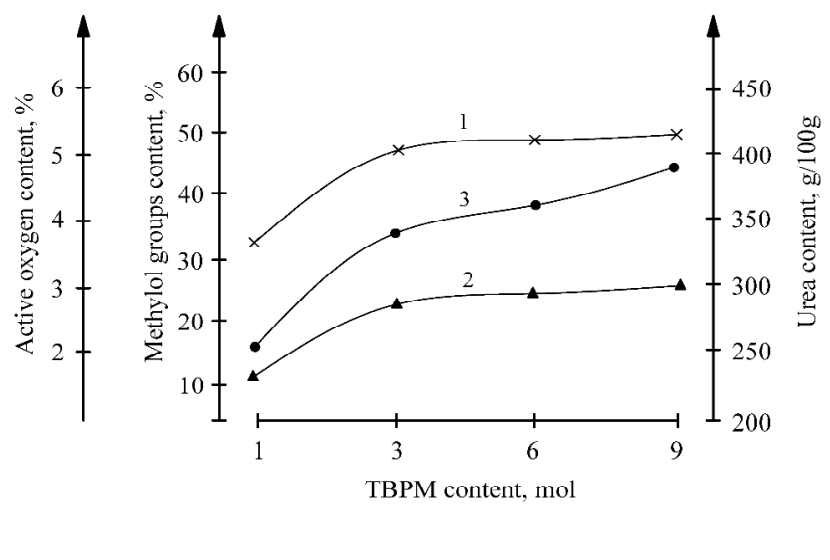

Fig. 3. Content of active oxygen (1) and methylol groups (2) in UFOP and oligomer yield (3) depending on the TBPM content. Molar ratio $\mathrm{U}: \mathrm{F}=1: 4 ; T=343 \mathrm{~K} ; t=3 \mathrm{~h}$

Table 1

Effect of formalin concentration on UFOP characteristics

\begin{tabular}{|c|c|c|c|c|c|}
\hline \multirow{3}{*}{ Formalin concentration, $\%$} & \multirow{3}{*}{ Yield, g/100 g urea } & \multicolumn{4}{|c|}{ Oligomer characteristics } \\
\hline & & \multirow{2}{*}{$\overline{M_{n}}, \mathrm{~g} / \mathrm{mol}$} & \multicolumn{3}{|c|}{ Content, \% } \\
\hline & & & {$[\mathrm{O}]_{a c t}$} & methylol groups & free formalin \\
\hline 32 & 375 & 250 & 5.5 & 29.7 & 0.26 \\
\hline 38 & 380 & 260 & 5.6 & 31.8 & 0.23 \\
\hline 40 & 378 & 260 & 5.6 & 31.4 & 0.28 \\
\hline
\end{tabular}


It is obvious from Fig. 1 that the highest content of active oxygen is observed in the compounds synthesized at $343 \mathrm{~K}$. Increasing the reaction temperature to $353 \mathrm{~K}$ reduces the number of peroxide groups in oligomers due to partial decomposition of -O-O- bonds, as well as due to the increase in the rate of the competitive reaction that occurs between the methylol derivatives of the formed oligomer. This is evidenced by the darkening of the resulting products and the reduction of the methylol groups content in the synthesized oligomers (Fig. 1b). At the same time, peroxide oligomers obtained at $353 \mathrm{~K}$ are poorly soluble in organic solvents due to their partial cross-linking during synthesis. The active oxygen content in the oligomers obtained at $323 \mathrm{~K}$ does not exceed $4.8 \%$, while the number of methylol groups remains virtually constant (Fig. 1). The reason is a low reaction rate of TBPM with methylol derivatives of urea at this temperature. In addition, the oligomers synthesized at $323 \mathrm{~K}$ are characterized by poor solubility in organic substances. The results shown in Fig. 1 indicate that at $\mathrm{U}: \mathrm{F}: \mathrm{TBPM}$ equal to $1: 4: 3 \mathrm{~mol}$, the optimum process temperature is $343 \mathrm{~K}$. It is also seen that the increase in the process time above $3 \mathrm{~h}$ practically does not increase the active oxygen content. Therefore, further experiments with the participation of TBPM were carried out at $343 \mathrm{~K}$ and process time of $3 \mathrm{~h}$.

One can see from Fig. 2 that when using 2-6 mol of formaldehyde, the active oxygen content in the oligomers is $5.5-5.6 \%$. The increase in formaldehyde content to $10 \mathrm{~mol}$ decreases the active oxygen content to $4 \%$, and increases the resulting product yield. The resulting products are opaque amorphous substances that are poorly soluble in organic solvents.

The introduction of $4 \mathrm{~mol}$ of formaldehyde per $1 \mathrm{~mol}$ of urea into the reaction mass makes it possible to obtain oligomers soluble in organic solvents with the maximum content of active oxygen (Fig. 2).

When studying the effect of the TBPM amount on the characteristics of the obtained oligomers (Fig. 3), the amount of $3 \mathrm{~mol}$ per $1 \mathrm{~mol}$ of urea was found to be the optimumThe reduction of TBPM amount to 1 mol leads to the decrease in the active oxygen content $(3.6 \%)$. On the other hand, the increase in TBPM content from 3 to $9 \mathrm{~mol}$ allows to slightly increase the active oxygen content (from 5.1 to $5.3 \%$ ). The yield of peroxide oligomers remains virtually constant.

Based on the researches, it can be argued that the optimal conditions for the synthesis of UFOP with the participation of TBPM are:

- $\mathrm{U}: \mathrm{F}$ : TBPM molar ratio is equal to $1: 4: 3$;

- process temperature is $343 \mathrm{~K}$;

- process time is $3 \mathrm{~h}$.

The effect of formalin concentration on the characteristics of the obtained oligomers was further studied. 32, 38 and $40 \%$ formalin solutions were used for the synthesis. The results obtained are given in Table 1. It was found that the content of active oxygen and methylol groups in the peroxide oligomer, as well as its molecular weight and yield are almost independent of the formalin concentration.

The above results were used to develop a method for the synthesis of UFOP with the participation of TBPM (UFOP-I), which is described in subsection 2.4. UFOP-I was characterized by a molecular weight of $280 \mathrm{~g} / \mathrm{mol}$, active oxygen content of $5.6 \%$, the content of methylol groups $31.2 \%$ and the yield of $378 \mathrm{~g}$ per $100 \mathrm{~g}$ of starting urea. UFOP-I is a viscous transparent compound, soluble in acetone, dioxane and other organic solvents and capable of combining with unsaturated oligoesters.

\subsubsection{Synthesis of UFOP in the presence of TBHP}

tert-Butyl hydroperoxide (TBHP), in comparison with TBPM, is a more available product, and also contains in its structure a mobile hydrogen atom capable of nucleophilic substitution with hydroxyl groups of alcohols and preservation of $-\mathrm{O}-\mathrm{O}-$ bond [23]. In this regard, we can assume that TBHP can react with methylol derivatives of urea by the following equation:

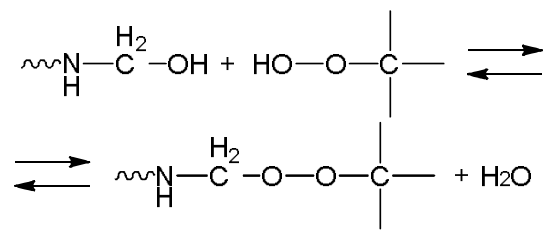

On the other hand, it is known [19] that even in the catalysts absence the TBHP is quite easy enters the condensation reaction with formaldehyde and forms TBPM by Eq. (3):

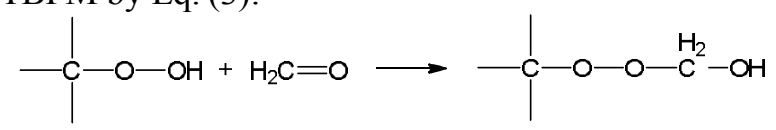

Thus we assume that TBHP, on the one hand, can react with methylol derivatives of urea according to Eq. (2), and on the other hand, can react with formaldehyde according to Eq. (3) with the formation of TBPM. The formed TBPM will react, as shown above, with methylol derivatives of urea.

In order to determine the direction of the reaction with the formation of UFOP, the interaction of TBHP with the individual components of the reaction mixture was studied.

Kinetic studies of the TBHP reaction with formaldehyde, urea and dimethylolurea were carried out at 293,303 and $313 \mathrm{~K}$ in the presence of zinc oxide in the amount of $0.1 \mathrm{wt} \%$ relative to the content of the amino compound. Process rate control was performed by changing the concentration of TBHP hydroperoxide groups. 
The kinetic studies procedure is given in subsection 2.3, and the results are shown in Fig. 4 and Table 2. The results (Fig. 4) show that the reaction rate of TBHP with formaldehyde in the presence of a catalyst is almost twice as high as in the absence of zinc oxide (Table 2). The obtained results confirm the possibility of the condensation reaction according to Eq. (3), and also indicate the need of using zinc oxide as a catalyst for this reaction.

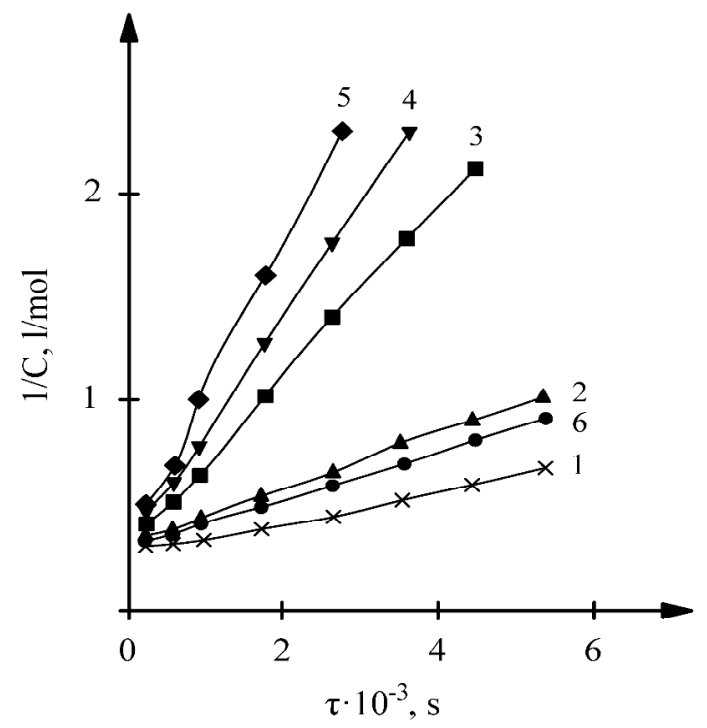

Fig. 4. 1/C vs. reaction time for the reaction of TBHP with formaldehyde $(1,2)$, a mixture of urea with formaldehyde (3-5) and dimethylolurea (6) at $293 \mathrm{~K}(1,2,3,6), 303 \mathrm{~K}(4)$ and $313 \mathrm{~K}(5)$ in the presence of zinc oxide (2-6)
Introduction of urea to the reaction mass, as evidenced by the data shown in Fig. 4, significantly increases the rate of TBHP consumption. In the absence of formaldehyde in the mixture, TBHP does not react with urea.

The increase in the reaction rate of TBHP and formaldehyde in the presence of urea, compared with the processes that occur without amino compound, indicates that the reaction proceeds according to Eq. (2).

To confirm the assumption, the process of TBHP with dimethylolurea (DMU) was studied. DMU was synthesized by the method described in [24]. As can be seen from Table 2, the rate constant of the TBHP reaction with DMU and reaction rate constant of TBHP with formaldehyde are almost the same.

The obtained results indicate that TBHP under the experimental conditions reacts with formaldehyde followed by TBPM formation, as well as with methylol derivatives of urea. The formed TBPM (vide Eq. 3) also interacts with the methylol groups of the amino compound.

Thus, the above results indicate the possibility of using TBHP for the UFOP synthesis. The process can be described by Eq. (1).

To determine the optimal conditions for the UFOP synthesis with the participation of TBHP, the effect of starting reagents ratio and process time on the oligomer yield and the content of active oxygen and methylol groups was studied. The reaction was studied at $343 \mathrm{~K}$, the molar ratio of $\mathrm{U}: \mathrm{F}:$ TBHP equal to $1:(2-10):(1-7)$, and the content of zinc oxide equal to $0.1 \mathrm{wt} \%$ relative to the amount of initial urea.

Table 2

Effective rate constants and activation energy for the reaction of TBHP and mixture reagents

\begin{tabular}{|c|c|c|c|c|c|c|c|}
\hline \multicolumn{3}{|c|}{ Reagents content, $\mathrm{mol} / \mathrm{mol}$ TBHP } & \multirow[t]{2}{*}{$\mathrm{ZnO}$} & \multicolumn{3}{|c|}{$K_{e f} 10^{4}(1 / \mathrm{mol} \cdot \mathrm{s})$ at the temperature, $\mathrm{K}$} & \multirow[t]{2}{*}{$E_{a c t}, \mathrm{~kJ} / \mathrm{mol}$} \\
\hline $\mathrm{F}$ & $\mathrm{U}$ & DMU & & 293 & 303 & 313 & \\
\hline 1.6 & 0.2 & - & + & 4.22 & 5.56 & 7.39 & 22.4 \\
\hline 1.6 & - & - & + & 1.43 & - & - & - \\
\hline 1.6 & - & - & - & 0.76 & - & - & - \\
\hline - & - & 0.5 & + & 1.28 & - & - & - \\
\hline
\end{tabular}

Notes: F - formaldehyde, U - urea, DMU - dimethylolurea

The method for conducting research is described in subsection 2.3, and the results are presented in Figs. 5-7.

The data represented in Fig. 6 show that the maximum content of active oxygen $(7.5 \%)$ is achieved when the formaldehyde content in the reaction mixture is 4 moles per mole of urea. The resulting compounds with low yields are solids, which are poorly soluble in organic solvents. Similar results were obtained by reducing the formaldehyde content in the mixture to $2 \mathrm{~mol}$ per mole of urea.
Liquid, transparent and well-soluble peroxide oligomers can be obtained when 6-10 mol of formaldehyde per mole of urea are presented in the reaction mixture. At the same time, the increase in the formaldehyde amount above $8 \mathrm{~mol}$ leads to the decrease in the active oxygen content, whereas the content of methylol groups in the oligomer and its yield are practically unchanged (Fig. 6). Therefore, the optimal amount of formaldehyde is $8 \mathrm{~mol}$ at $\mathrm{U}$ : TBHP ratio of 1:5 moles. 


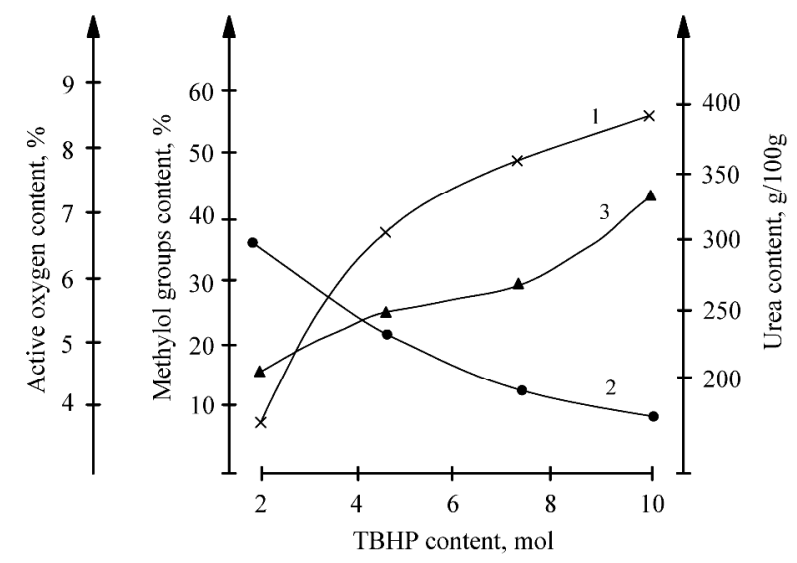

Fig. 5. Content of active oxygen (1), methylol groups (2) in UFOP and the oligomer yield (3) depending on the TBHP content. Molar ratio $\mathrm{U}: \mathrm{F}=1: 4 ; T=343 \mathrm{~K}, t=3 \mathrm{~h}$

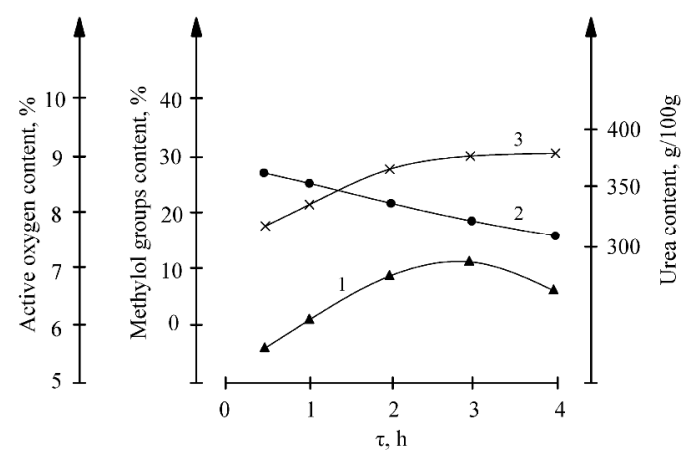

When studying the effect of the synthesis tme, it was found (Fig. 7) that the maximum content of peroxide groups is achieved in $3 \mathrm{~h}$. This allowed us to propose a process temperature of $343 \mathrm{~K}$ and time of $3 \mathrm{~h}$. The obtained results formed the basis for the development of UFOP synthesis method with the participation of TBHP (UFOP-II), which is presented in subsection 2.4.

UFOP-II was characterized by a molecular weight of $370 \mathrm{~g} / \mathrm{mol}$, an active oxygen content of $7.1 \%$ and the content of methylol groups $19.8 \%$. The oligomer yield was $390 \mathrm{~g}$ per $100 \mathrm{~g}$ of starting urea. UFOP-II is a storage-stable liquid substance, soluble in organic solvents and able to combine with unsaturated oligoesters.

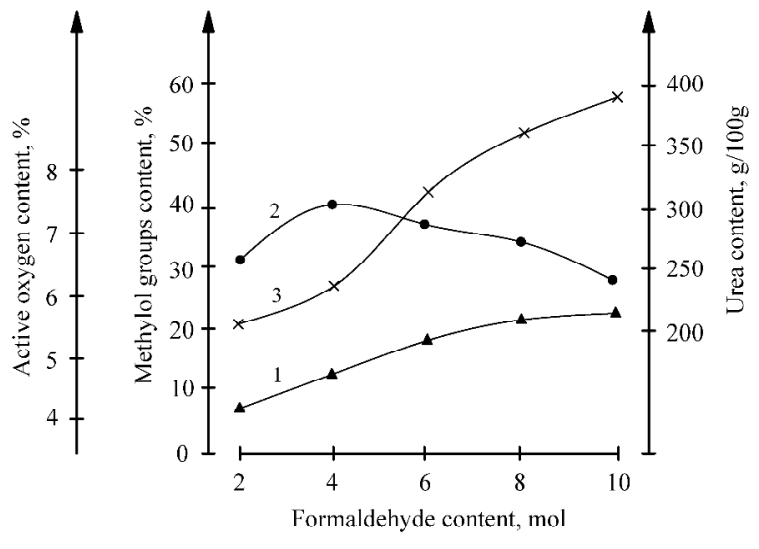

Fig. 6. Content of active oxygen (1), methylol groups (2) in UFOP and the oligomer yield (3) depending on the F content. Molar ratio $\mathrm{U}: \mathrm{TBHP}=1: 5 ; T=343 \mathrm{~K}, t=3 \mathrm{~h}$

Fig. 7. Content of active oxygen (1), methylol groups (2) in UFOP and the oligomer yield (3) depending on the process time. Molar ratio $\mathrm{U}: \mathrm{F}: \mathrm{TBHP}=1: 8: 5 ; T=343 \mathrm{~K}$

\subsection{UFOP Structure}

To confirm the structure of the synthesized peroxide oligomers (UFOP-I and UFOP-II), their IR and NMR spectra were recorded. Interpretation of the spectra is given in Table 3.

The presence of weak absorption bands at $840 \mathrm{~cm}^{-1}$ in the spectrum of the oligomer UFOP-I, $880 \mathrm{~cm}^{-1}$ in the spectrum of UFOP-II, a doublet of deformation vibrations $\left(\mathrm{CH}_{3}\right)_{3} \mathrm{C}-$ at 1385 and $1365 \mathrm{~cm}^{-1}$ (UFOP-I), 1380 and $1360 \mathrm{~cm}^{-1}$ (UFOP-II), as well as $v_{\mathrm{CO}}(\mathrm{COOC})$ at $1190 \mathrm{~cm}^{-1}$ indicates the presence of peroxide fragments in the molecules of the synthesized oligomers.

Table 3

IR- and NMR-spectroscopic characteristics of UFOP

\begin{tabular}{|c|c|c|c|c|c|c|c|c|c|c|}
\hline \multirow{3}{*}{ UFOP } & \multicolumn{7}{|c|}{ IR spectrum, $\mathrm{cm}^{-1}$} & \multicolumn{3}{|c|}{ NMR spectrum, ppm } \\
\hline & $-\mathrm{O}$ & \multicolumn{2}{|c|}{$-\mathrm{NH}-\mathrm{CO}-\mathrm{NH}-$} & \multirow{2}{*}{$\begin{array}{c}-\mathrm{COC}- \\
-\mathrm{COH} \\
v_{\mathrm{CO}}\end{array}$} & \multicolumn{3}{|c|}{$\left(\mathrm{CH}_{3}\right)_{3} \mathrm{COO}-$} & \multirow{2}{*}{$\left(\mathrm{CH}_{3}\right)_{3} \mathrm{COO}-$} & \multirow{2}{*}{$\begin{array}{l}-\mathrm{NCH}_{2} \mathrm{~N}- \\
-\mathrm{NCH}_{2} \mathrm{O}-\end{array}$} & \multirow{2}{*}{$\begin{array}{c}-\mathrm{OH} \\
-(\mathrm{NH})-\end{array}$} \\
\hline & $v_{\mathrm{OH}}$ & $\begin{array}{c}\text { Amide I } \\
v_{\mathrm{CO}}\end{array}$ & $\begin{array}{c}\text { Amide II } \\
v_{\mathrm{NH}}+v_{\mathrm{CN}}\end{array}$ & & $\delta_{(\mathrm{CH} 3)_{3} \mathrm{C}-}$ & $\begin{array}{r}v_{\mathrm{CO}} \\
-\mathrm{COOC}-\end{array}$ & $v_{\mathrm{OO}}$ & & & \\
\hline UFOP-I & 3380 & 1660 & 1540 & $\begin{array}{l}1260 \\
1060\end{array}$ & $\begin{array}{l}1385 \\
1365\end{array}$ & 1190 & 840 & 1.15 & $4.65-5.05$ & $6.8-6.95$ \\
\hline UFOP-II & 3400 & 1660 & 1540 & $\begin{array}{c}1260 \\
980\end{array}$ & $\begin{array}{l}1380 \\
1360\end{array}$ & 1190 & 880 & 1.13 & $4.5-5.5$ & 6.9 \\
\hline
\end{tabular}


The UFOP structure is also confirmed by the absorption bands in the IR spectra: Amide I $\left(1660 \mathrm{~cm}^{-1}\right)$, Amide II $\left(1540 \mathrm{~cm}^{-1}\right)$; stretching vibrations of methylol groups at 3400 and $3380 \mathrm{~cm}^{-1}\left(v_{\mathrm{OH}}\right)$ and $1250-1000 \mathrm{~cm}^{-1}$ $\left(v_{\mathrm{CH}}\right)$. The presence of an ether bond is indicated by the absorption band at $1060-980 \mathrm{~cm}^{-1}$.

The analysis of NMR spectra indicates that the peroxide fragments correspond to the signal (singlet) in the region of 1.13 and $1.15 \mathrm{ppm}$, which belong to the protons of the $\left(\mathrm{CH}_{3}\right)_{3} \mathrm{C}-$ group. In the area of $4.5-$ $5.05 \mathrm{ppm}$ a signal typical of protons in $-\mathrm{NCH}_{2} \mathrm{O}-$ and $-\mathrm{NCH}_{2} \mathrm{~N}$ - was found. At the same time, the signals of -NH- and HO- groups could not be separately identified due to the rapid exchange of protons between them. Signals at 6.8-6.95 ppm belong to the NO group and were determined according to their shift toward the high field (6.75 ppm) when heated to $333 \mathrm{~K}$.

To confirm the structure of the oligomers, the ratios of the integrated intensities of the proton signals of $\left(\mathrm{CH}_{3}\right)_{3} \mathrm{COO}-$ groups and the sum of the proton signals of $-\mathrm{NCH}_{2} \mathrm{O}$ - and $-\mathrm{NCH}_{2} \mathrm{~N}$ - were calculated, which are in agreement with the results given in Table 3 .

\section{Conclusions}

Urea-formaldehyde oligomers UFOP-I or UFOP-II with peroxide groups were synthesized via the reactions of urea, formaldehyde and tert-butyl peroxymethanol or tertbutyl hydroperoxide in the presence of zinc oxide as the catalyst. The highest content of peroxide groups in UFOPI was found to be at the temperature of $343 \mathrm{~K}$, the process time of $3 \mathrm{~h}$ and urea : formaldehyde : tert-butyl peroxymethanol molar ratio of 1:4:3. UFOP-I is characterized by molecular weight of $280 \mathrm{~g} / \mathrm{mol}$, peroxide groups content of $5.6 \%$ and methylol groups content of $31.2 \%$. The product yield is $378 \mathrm{~g}$ per $100 \mathrm{~g}$ of urea. In the case of tert-butyl hydroperoxide, the ratio of urea : formaldehyde : tert-butyl hydroperoxide was 1:8:5 moles. UFOP-II contains $7.1 \%$ of peroxide groups, $19.8 \%$ of methylol groups and has a molecular weight of $370 \mathrm{~g} / \mathrm{mol}$. The product yield is $390 \mathrm{~g}$ per $100 \mathrm{~g}$ of urea. The process proceeds at a temperature of $343 \mathrm{~K}$ and reaction time of $3 \mathrm{~h}$. The synthesized oligomers are well soluble in organic solvents and are able to combine with other polymers, in particular with oligoesteracrylates. The structure of the synthesized oligomers was confirmed by IR- and NMR-spectroscopic studies. Peroxide groups in UFOP-I are proved by the presence of stretching vibrations at $840 \mathrm{~cm}^{-1}$ and a doublet of deformation vibrations of the $\left(\mathrm{CH}_{3}\right)_{3} \mathrm{C}-$ group at 1385 and $1365 \mathrm{~cm}^{-1}$. In the NMR spectrum, peroxide groups are proved by the signal of protons in the $\left(\mathrm{CH}_{3}\right)_{3} \mathrm{COO}-$ group at $1.15 \mathrm{ppm}$. For UFOP-II, peroxide groups are proved by stretching vibrations of $-\mathrm{O}-\mathrm{O}-$ bond at $880 \mathrm{~cm}^{-1}$ and gem-dimethyl vibrations at 1380 and $1360 \mathrm{~cm}^{-1}$. In the NMR spectrum there are signals of protons of the peroxide group in the region of $1.13 \mathrm{ppm}$. Both synthesized oligomers contain methylol groups in their structure, as evidenced by the absorption bands in the IR spectrum at 3400 and $3380 \mathrm{~cm}^{-1}$ $\left(v_{\mathrm{OH}}\right)$ and $1250-1000 \mathrm{~cm}^{-1}\left(v_{\mathrm{CH}}\right)$. The presence of nitrogen atoms in oligomers is confirmed by the absorption bands in the IR spectrum at 1660 and $1540 \mathrm{~cm}^{-1}$ characterized by Amide-I and Amide-II. In the NMR spectra, the proton signals of the above groups correspond to $4.6-5.5 \mathrm{ppm}$.

\section{References}

[1] HetmanchukYu., Bratychak M.: Khimia i Technologia Polimeriv. Beskid-Bit, Lviv 2006.

[2] Bratychak M., HetmanchukYu.: Khimichna Technologia Syntezu Vysokomolekuliarnykh Spoluk. Vyd-vo Lviv. Polytechnik, Lviv 2009.

[3] Bratychak M., Shyshchak O., Astakhova O., Ivashkiv O.: Oligomers with Functional Groups Based on Epoxy Resins.

Synthesis, Properties and Application. Lviv Polytechnic Publ. House, Lviv 2019.

[4] Hetmanchuk Yu., Bratychak M.: Khimiya i Technologiya Oligomeriv. Vyd-vo Kyiv Univ., Kyiv 2008.

[5] Bratychak M., Bratychak Mykh. Mykh.: Peroksydni Pokhidni Epoksydnykh Smol. Vyd-vo Lviv. Polytechnik, Lviv 2003.

[6] Zherebin Yu., Ivanchev S., Domareva N.: Vysokomol. Soed., 1974, 16, 893.

[7] Ivashkiv O., Namiesnik Ja., Astakhova O. et al.: Chem. Chem. Technol., 2015, 9, 313. https://doi.org/10.23939/chcht09.03.313

[8] Bashta B., Bruzdziak P., Astakhova O. et al.: Chem. Chem. Technol., 2013, 7, 413. https://doi.org/10.23939/chcht07.04.413 [9] Zubyk H., Plonska-Brzezinska M., Shyshchak O. et al.: Chem. Chem. Technol., 2015, 9, 435.

https://doi.org/10.23939/chcht09.04.435

[10] Strap G., Astakhova O., Lazorko O. et al.: Chem. Chem. Technol., 2013, 7, 279. https://doi.org/10.23939/chcht07.03.279

[11] Bratychak M., Berezovska N.: Ukr. Khim. Zh., 1994, 60, 96.

[12] Aneli J., Shamanauri L., Markarashvili E. et al.: Chem. Chem.

Technol., 2017, 11, 201. https://doi.org/10.23939/chcht11.02.201

[13] Karandashov O., AvramenkoV.: Chem. Chem. Technol., 2017,

11, 61. https://doi.org/10.23939/chcht11.01.061

[14] https://www.sciencedirect.com/topics/engineering/amino-resin

[15] https://scielo.conicyt.cl/scielo.php?script=sci

arttext\&pid=S0717-97072020000404966

[16] https://www.fpl.fs.fed.us/documnts/pdf1991/ebewe91a.pdf 
[17] https://ihsmarkit.com/products/amino-resins-chemicaleconomics-handbook.html

[18] Knuniants I. (Ed.): Khimicheskyi Encyclopedicheskyi Slovar, Moskva 1983.

[19] Rakhimov A.: Khimia i Tekhnologia Organicheskykh Perekisnykh Soedinenii. Khimia, Moskva 1979.

[20] Antonovskyi L., Buzlanova M.: Analiticheskaya Khimia Organicheskykh Perekisnykh Soedinenii. Khimia, Moskva 1978.

[21] Sukhanova N., Shuvalova L.: Lakokrasochnye Materialy i ikh Primenenie, 1981, 4, 47.

[22] Ivanov V. (Ed.): Rukovodstvo k Prakticheskym Rabotam po Khimii Polimerov. Izd-vo Leningr. Univ., Leningrad 1982.

[23] Antonovskyi V.: Organicheskie Perekisnye Initsiatory. Khimia, Moskva 1972.

[24] Virshpa Z., Bzezinsky Ya.: Aminoplasty. Khimia, Moskva 1973.

Received: December 13, 2020 / Revised: December 21, 2020 / Accepted: January 15, 2021

\section{СИНТЕЗ ТА БУДОВА СЕЧОВИНО- ФОРМАЛЬДЕГІДНИХ ОЛІГОМЕРІВ З ПЕРОКСИДНИМИ ГРУПАМИ}

Анотація. Розглянута можсливість синтезу в присутності трет.-бутилпероксиметанолу (ТБПМ) або трет.-бутилгідропероксиду (ТБГП) сечовино-формальдегідних олігомерів 3 пероксидними групами (СФОП). Як каталізатор реакції використаний оксид ичнку. Вивчений вплив співвідномення вихідних компонентів, температури реакиіі та тривалості прочесу на характеристику та вихід отримуваних олігомерів. Запропоновані методики одержсання СФОП з використанням як компонента суміші ТБПМ і ТБГП. Будова синтезованих СФОП підтверджена ІЧ- і ПМР-спектроскопічними дослідженнями.

Ключові слова: сечовина, формальдегід, сечовиноформальдегідні олігомери, пероксид, гідропероксид, оксид ичику, ІЧ- і ПМР-дослідження. 